\title{
Recent Hybridization between a Polar Bear and Grizzly Bears in the Canadian Arctic
}

\author{
Jodie D. Pongracz, ${ }^{1}$ David Paetkau, ${ }^{2}$ Marsha Branigan ${ }^{1,3}$ and Evan Richardson ${ }^{4}$
}

(Received 22 June 2016; accepted in revised form 24 October 2016)

\begin{abstract}
Grizzly bears have recently become more common on the Arctic Islands in the Inuvialuit Settlement Region, concurrently with a period of environmental change. Over the last decade, grizzly bear-polar bear hybrids have been confirmed within this region, triggering extensive discussion and speculation regarding the impact of hybridization on the parent species. Through harvests, sightings, and captures, we document an increase in the presence of grizzly bears and combine field observations of hybrids with genetic analysis and parentage analysis to identify four first-generation (F1) hybrids and four offspring of F1 hybrids and grizzly bears (backcross-to-grizzly-bear individuals). We trace these eight hybrid individuals to a single female polar bear who mated with two grizzly bears. We sampled one of her mates on the sea ice in the High Arctic and deduced the genotype of the other from his five offspring. The two male grizzly bears are sires of both the F1 generation and the backcross-to-grizzly-bear generation. So what initially appeared to be a sudden spate of hybridization in the western Canadian Arctic originated with the unusual mating between three non-hybrid parents. The breakdown of species barriers may start with atypical mating preferences of select individuals; however, the story we present can be traced to a single female polar bear who, along with three of her known F1 offspring, has been killed.
\end{abstract}

Key words: polar bear; Ursus maritimus; grizzly bear; Ursus arctos; hybrid; microsatellites; High Arctic; Northwest Territories; Viscount Melville Sound

RÉSUMÉ. La présence du grizzli se fait plus courante dans l'archipel Arctique de la région désignée des Inuvialuit depuis un certain temps, ce qui coïncide avec une période de changement environnemental. Ces dix dernières années, la présence d'ours polaires-grizzlis hybrides a été confirmée dans cette région, ce qui a déclenché d'importantes discussions et hypothèses relativement aux incidences de l'hybridation sur les espèces apparentées. Au moyen de récoltes, d'observations et de captures, nous avons documenté l'augmentation de la présence de grizzlis, alliées à des observations d'hybrides sur le terrain avec analyse génétique et analyse de parenté afin d'identifier quatre hybrides de première génération (F1) et quatre descendants d'hybrides F1 et de grizzlis (individus issus de rétrocroisements avec un grizzli). Nous faisons remonter ces huit hybrides à une seule ourse polaire qui s'est accouplée avec deux grizzlis. Nous avons prélevé un échantillon d'un de ses compagnons sur la glace de mer de l'Extrême-Arctique et avons déduit le génotype de l'autre à partir de ses cinq descendants. Les deux grizzlis mâles sont des géniteurs de la génération F1 et de la génération du rétrocroisement avec un grizzli. Donc, ce qui semblait être, au début, une montée soudaine d'hybridation dans l'ouest de l'Arctique canadien est attribuable à l'accouplement inhabituel de trois parents non hybrides. La rupture des obstacles auxquels les espèces font face pourrait commencer par les préférences d'accouplement atypiques de certains individus. Toutefois, la situation dont il est ici question remonte à une seule ourse polaire qui a été tuée, avec trois de ses descendants connus de la génération F1.

Mots clés : ours polaire; Ursus maritimus; grizzli; Ursus arctos; hybride; microsatellites; Extrême-Arctique; Territoires du Nord-Ouest; détroit du Vicomte de Melville

Traduit pour la revue Arctic par Nicole Giguère.

\section{INTRODUCTION}

The close and complex evolutionary relationship between polar bears (Ursus maritimus) and brown bears (Ursus arctos) (hereafter referred to as grizzly bears) has been investigated intensively over the past decade (Hailer et al.,
2012; Miller et al., 2012; Cahill et al., 2013, 2015; Cronin et al., 2013; Liu et al., 2014). The most recent studies have used genome-wide surveys of many individuals and point to a history in which geographically and temporally localized introgression has played an important role in the evolutionary ecology of these two species (Cahill et al., 2015).

\footnotetext{
${ }^{1}$ Wildlife Management, Environment and Natural Resources, Government of the Northwest Territories, PO Box 2749, Inuvik, Northwest Territories X0E 0T0, Canada

${ }^{2}$ Wildlife Genetics International, Box 274, Nelson, British Columbia V1L 5P9, Canada

${ }^{3}$ Corresponding author: Marsha_Branigan@gov.nt.ca

${ }^{4}$ Wildlife Research Division, Science and Technology Branch, Environment and Climate Change Canada, Edmonton, Alberta T6H 3S5, Canada

(C) The Arctic Institute of North America
} 
Hailer et al. (2012) suggest that the polar bear mitochondrial lineage was replaced by a grizzly bear variant approximately 150000 years ago, some hundreds of thousands of years after the nuclear genomes of the two species had assumed independent evolutionary trajectories. More recently, there is evidence of unidirectional gene flow from polar bears into the grizzly bears of southeastern coastal Alaska: it is posited that a southern polar bear population became isolated there at the end of the Pleistocene and was "captured" by male-mediated gene flow from the regional grizzly bear population (Cahill et al., 2013, 2015). Whereas no evidence has been found for the flow of grizzly bear genes into the polar bear genome on the time scale of 10000 to 100000 years, certain island populations of grizzly bears in southeastern Alaska have substantially introgressed genomes, with the polar bear component approaching 10\% (Cahill et al., 2015). These studies by Hailer et al. (2012) and Cahill et al. (2013, 2015) provide strong evidence for introgression on an evolutionary time scale, but evidence for contemporary hybridization in the wild is lacking (Cronin and MacNeil, 2012, microsatellites; Cronin et al., 2013, amplified fragment length polymorphism and mtDNA; and Cronin et al., 2014, single nucleotide polymorphisms).

Although grizzly bear and polar bear ranges overlap along the northern coasts of North America, Asia, and Europe, polar bears are generally expected to be offshore hunting seals - and thus separated from their terrestrial sister species-during their mating season. However, since 2004 (Doupé et al., 2007), it has become increasingly common to observe grizzly bears north of their traditional range, sometimes $500 \mathrm{~km}$ or more from the mainland coast, well into the range of polar bears in the Canadian Arctic Archipelago. In 2006, the hunting of a hybrid bear near Sachs Harbour, Northwest Territories, received broad coverage in the popular press, stimulating concerns that, as a result of warming climate and an expanding grizzly bear range, polar bears might be reabsorbed into their more abundant sister species.

In this manuscript we document the increased presence of grizzly bears in the western portion of the Canadian Arctic Archipelago and combine field observations with parentage analysis and genetic assignments of individual ancestry to investigate hybridization events within this region since 2006 .

\section{METHODS}

We document observations from the Arctic Islands in the Inuvialuit Settlement Region of the Northwest Territories (Fig. 1). There are two Inuvialuit communities within the area: Sachs Harbour, located on southwestern Banks Island, and Ulukhaktok, located on the Diamond Jenness Peninsula on the western coast of Victoria Island. Average annual temperatures range from $-14^{\circ} \mathrm{C}$ to $-18^{\circ} \mathrm{C}$; cold and dry climatic conditions persist, with blowing snow occurring

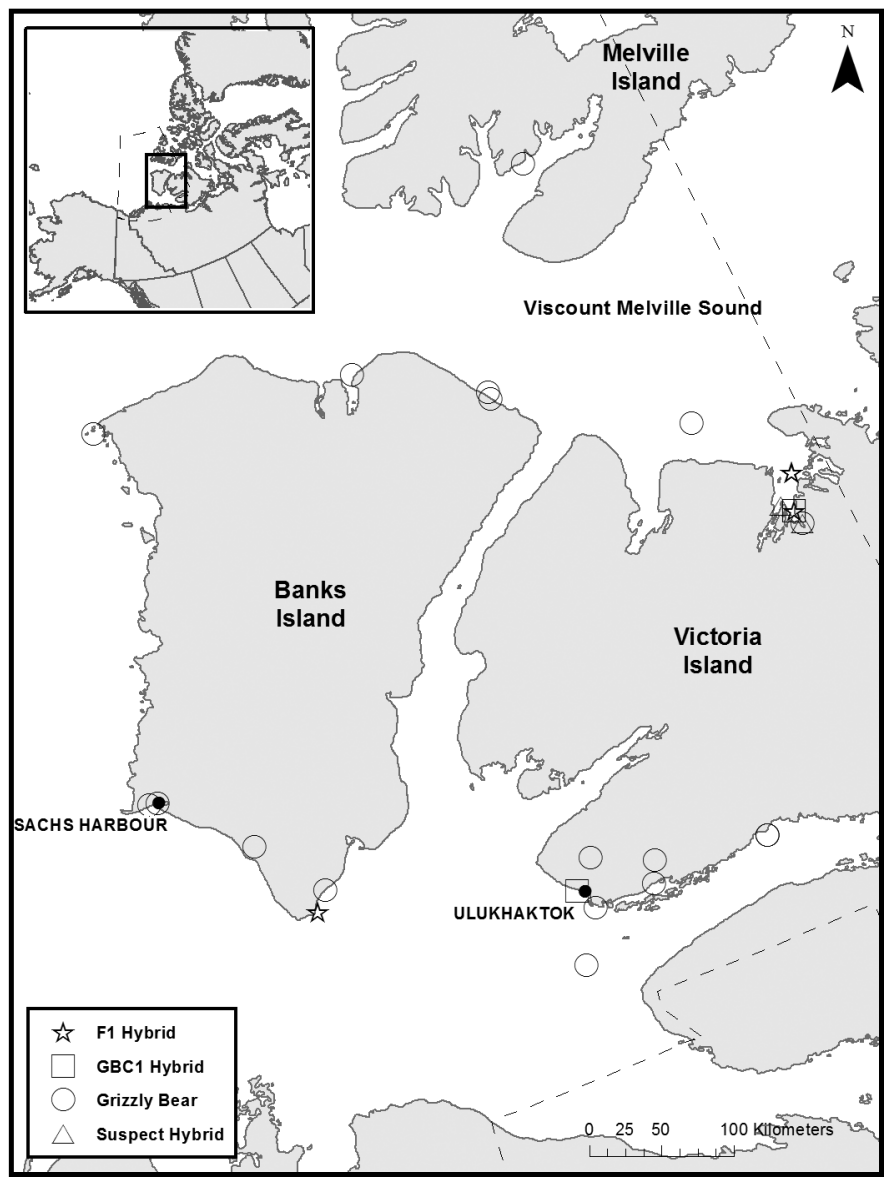

FIG. 1. The location of grizzly bears, first-generation hybrids (F1), backcrossto-grizzly-bear hybrids (GBC1), and suspect hybrid bears that were sighted and photographed, captured, or harvested in the western Arctic Archipelago of the Canadian Arctic.

from 60 to more than 90 days per year (Hudson et al., 2001). The Arctic Islands are surrounded by sea ice from late October through early June (Canadian Ice Service, 2013).

Our observations consist of documented sightings, killings (hereafter referred to as harvests), and capture (immobilization) events (Table 1, Fig. 1), the latter two of which yielded tissue samples for DNA analysis. Capture and handling protocols for bears followed the guidelines of the Canadian Council on Animal Care and were approved by the NWT Wildlife Care Committee. Tissue samples, which consisted of a small skin or flesh sample or mouth swab (cotton swab of inside of mouth), were stored dry in paper envelopes.

To date, samples from 25 individuals have been genotyped, including four putative first-generation (F1) hybrids, four putative second-generation grizzly bear backcross hybrids (GBC1), a female polar bear that was harvested in the company of two of the hybrids, and 16 grizzly bears that were sampled in the Arctic Islands to the north of the historic species range. To establish individual identity, sex, and population of origin, these samples were analyzed at 15 microsatellite markers (G10B, G1D, G10M, G10P, MU50, MU59, G10J, G10H, G1A, G10C, G10L, G10X, CXX110, CXX20, G10U) plus the 
TABLE 1. Recent harvests, captures, and sightings of grizzly bears, first-generation hybrid bears (F1), backcross-to-grizzly-bears (GBC1), and suspect hybrids in the western Arctic Islands, Northwest Territories.

\begin{tabular}{|c|c|c|c|c|c|c|}
\hline Species & ID & Date & $\operatorname{Sex}^{1}$ & $\mathrm{Age}^{2}$ & Genotyped & Type \\
\hline Grizzly bear & 2289 & 05 January 2001 & M & 5 & Yes & Harvest \\
\hline Grizzly bear & G678 & 02 May 2006 & M & 10 & Yes & Harvest \\
\hline Grizzly bear & 8260 & 15 June 2009 & M & 5 & Yes & Harvest \\
\hline Grizzly bear & XXXX & 11 May 2010 & M & 4 & Yes & Harvest \\
\hline Grizzly bear & 8931 & 10 June 2010 & M & 4 & Yes & Harvest \\
\hline Grizzly bear & 9472 & 13 August 2011 & M & 2 & Yes & Harvest \\
\hline Grizzly bear & 9763 & 04 July 2012 & $\mathrm{~F}$ & 2 & Yes & Harvest \\
\hline Grizzly bear & 9785 & 11 May 2013 & M & 6 & Yes & Harvest \\
\hline Grizzly bear & 9764 & 17 May 2013 & M & 3 & Yes & Harvest \\
\hline Grizzly bear & 9765 & 31 May 2013 & $\mathrm{~F}$ & 2 & Yes & Harvest \\
\hline Grizzly bear & 9766 & 31 May 2013 & $\mathrm{~F}$ & 2 & Yes & Harvest \\
\hline Grizzly bear & 9767 & 31 May 2013 & M & 2 & Yes & Harvest \\
\hline Grizzly bear & 10158 & 28 June 2014 & M & $3-5$ & Yes & Harvest \\
\hline Grizzly bear & (photo) & 23 April 2012 & $\mathrm{U}$ & $\mathrm{U}$ & N/A & Sighting (photo) \\
\hline Grizzly bear & X32854 & 25 April 2012 & M & 21 & Yes & Capture \\
\hline Grizzly bear & X15817 & 31 May 2012 & M & 16 & Yes & DNA dart \\
\hline Grizzly bear & X15714 & 05 May 2013 & M & 16 & Yes & Capture \\
\hline Grizzly bear & (photo) & 05 May 2013 & $\mathrm{U}$ & $\mathrm{U}$ & N/A & Sighting (photo) \\
\hline Grizzly bear & X15817 & 12 May 2014 & M & 18 & Yes & Capture \\
\hline F1 hybrid & 6505 & 16 April 2006 & M & 6 & Yes & Harvest \\
\hline Backcross-to-grizzly-bear & 8930 & 08 April 2010 & M & 3 & Yes & Harvest \\
\hline F1 hybrid & 10958 & 19 April 2012 & $\mathrm{~F}$ & 2 & Yes & Harvest \\
\hline F1 hybrid & 10959 & 19 April 2012 & $\mathrm{~F}$ & 2 & Yes & Harvest \\
\hline Suspect hybrid & (photo) & 23 April 2012 & $\mathrm{U}$ & $\mathrm{U}$ & $\mathrm{N} / \mathrm{A}$ & Sighting (photo) \\
\hline Suspect hybrid & (photo) & 25 April 2012 & $\mathrm{U}$ & $\mathrm{U}$ & N/A & Sighting (photo) \\
\hline F1 hybrid & $\mathrm{X} 15718$ & 14 April 2014 & $\mathrm{~F}$ & 11 & Yes & Capture \\
\hline Backcross-to-grizzly-bear & X15719 & 14 April 2014 & M & 0 & Yes & Capture \\
\hline Backcross-to-grizzly-bear & $\mathrm{X} 15720$ & 14 April 2014 & M & 0 & Yes & Capture \\
\hline Backcross-to-grizzly-bear & X15721 & 14 April 2014 & M & 0 & Yes & Capture \\
\hline
\end{tabular}

${ }^{1} \mathrm{U}=$ unknown.

${ }^{2} \mathrm{U}=$ unknown, $0=$ cubs of the year.

sex-linked amelogenin marker (Ennis and Gallagher, 1994). The microsatellite markers were selected on the basis of availability of large reference sets for polar bears (Paetkau et al., 1999) and northern grizzly bear populations from Nunavut, Yukon, and the Northwest Territories. The primer sequences and analysis conditions are described elsewhere (Paetkau et al., 1998a); genotypes were scored using the same calibration as in the published reference sets.

Large reference sets were available for the regional polar bear and grizzly bear populations, but in addition, in order to assess our power to assign ancestry using 15-locus microsatellite genotypes, we created simulated genotypes of both purebred and hybrid ancestries. Using the "rand()" function in Microsoft Excel, we drew alleles at random, with replacement, from the allele frequency distributions observed in Southern Beaufort polar bears (Paetkau et al., 1999; $n=30$ ) and northern Northwest Territories grizzly bears (Government of the Northwest Territories, Environment and Natural Resources, unpubl. data; $n=30$ ). To create grizzly bear backcross (GBC1) genotypes, we drew one allele from the grizzly bear distribution and one allele from an F1 genotype in which one allele had been drawn from each parental species. Such individuals will, on average, have a grizzly bear genotype at half of the markers for which genotypes are drawn and one allele from either species at the remainder of markers. We repeated this process 4000 times, drawing 1000 genotypes of each parental species, $1000 \mathrm{~F} 1$ genotypes, and $1000 \mathrm{GBCl}$ genotypes.

Software packages that estimate probabilities for a given parentage hypothesis are based on allele frequencies within the study population. This framework does not apply to our situation, where the relationships start with two highly divergent populations (grizzly bears and polar bears) and then pass through hybrid generations. We therefore assessed relationships using the simple Mendelian expectation that a parent and offspring will share an allele at each marker. We anticipated that this approach would be unusually powerful for hybrid individuals, since many alleles have very different frequencies in the two species, reducing the number of individuals in either parental population that will share an allele with a given offspring.

The initial parentage search with 15-locus genotypes placed all eight putative F1 $(10958,10959,6505$, X15718) and $\mathrm{GBC} 1$ (X15719, X15720, X15721, 8930) individuals as the offspring or grand-offspring of the same female polar bear (10960). It also identified a male grizzly bear whose genotype was consistent with paternity of three of eight hybrids (X32854). We then added six additional microsatellites (MU23, REN145P07, REN144A06, MSUT2, MU51, and CPH9; Taberlet et al., 1997; Kitahara et al., 2000; Breen et al., 2001) to the genotypes of these 10 pivotal individuals. To confirm maternal ancestry, we 


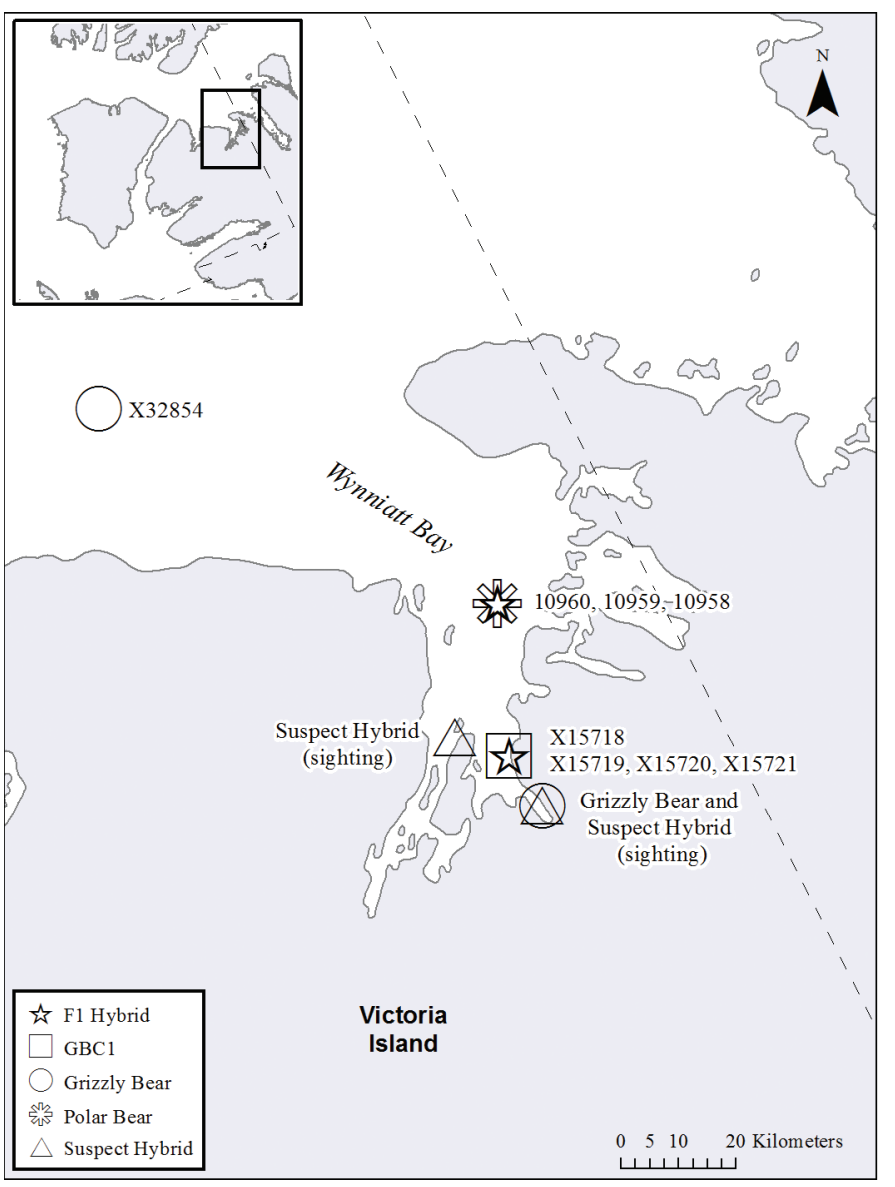

FIG. 2. The location of grizzly bears, first-generation hybrids (F1), backcrossto-grizzly-bear hybrids (GBC1), and suspect hybrid bears that were sighted and photographed, captured, or harvested along the north shores of Victoria Island.

performed a partial sequence analysis of the mitochondrial 16S rRNA gene (primers: AGA CGA GAA GAC CCT ATG GAG CTT and TTC TCC GAG GTC ACC CCA AC), an analysis that resolves the mitochondrial lineage of northern Canadian grizzly bears from the lineage seen in polar bears and the grizzly bears of southeastern Alaska (clades III and I, respectively, of Waits et al., 1998).

\section{RESULTS}

We documented 13 grizzly bears harvested by hunters in the Arctic Islands of the western Canadian Archipelago (Figs. 1, 2), three of which were females (Table 1). Three grizzly bears were also captured in the Viscount Melville Sound region, one of which (X32854) was captured on the sea ice approximately $25 \mathrm{~km}$ from land. One of the captured bears had also been DNA-darted two years before its capture. There were also two sightings of grizzly bears from which no sample was obtained. One sighting was off the coast of northwestern Banks Island, where a grizzly bear was captured the subsequent year. The second sighting was in the Wynniatt Bay area of Victoria Island, where the grizzly bear was on the sea ice with a bear that appeared to

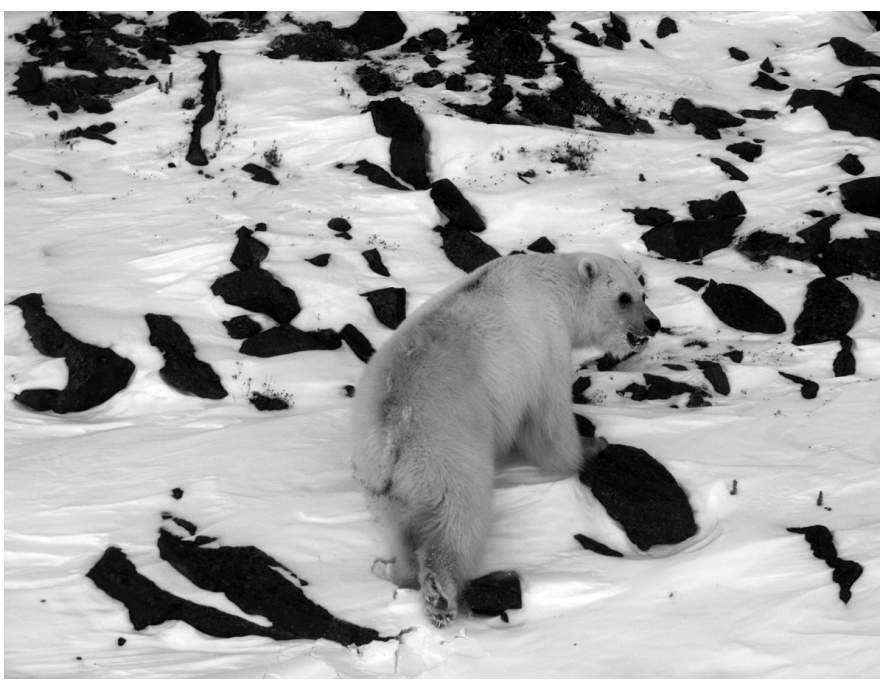

FIG. 3. Photograph of suspect hybrid (not sampled) initially observed with a grizzly bear (not sampled) in the Wynniatt Bay region of Victoria Island in April 2012. Photo (C) Jodie Pongracz, Environment and Natural Resources, Government of the Northwest Territories.

be a hybrid but was not sampled (Figs. 2, 3). The 16 Arctic Island grizzly bears from which we obtained samples included three two-year-old females and 13 males of ages 2-21 (Table 1).

Our field observations included two apparent family groups comprising five putative mother-offspring relationships: the female polar bear 10960 was harvested alongside two two-year-old offspring $(10958,10959)$ that appeared to be hybrids, and the female X15718, who had the appearance of a hybrid, was live-captured in the presence of three cubs-of-the-year (X15719, X15720, X15721) (presumed GBC1 bears). In both cases, the adult females (10960, X15718) shared alleles at all 21 microsatellite markers with each of the accompanying young bears. Interestingly, both X15718 and the original Sachs bear (6505) shared alleles at all markers with the female polar bear (10960), suggesting that 10960 is the mother of all four F1s $(10958,10959,6505, \mathrm{X} 15718)$ documented to date. The fourth and final bear whose appearance was suggestive of GBC1 status (8930) also shared alleles at all markers with $\mathrm{X} 15718$, placing this female as the putative mother of all four GBC1 bears in our sample set. Thus, all eight putative hybrids sampled were placed into a single family of three generations (Fig. 4).

Of the eight apparent mother-offspring relationships that we identified, five involved offspring that were sampled with their mothers and thus are almost certain to be true mother-offspring pairs. In the other three cases, there is a possibility that the observed pattern of allele sharing occurred by chance between individuals that had a relationship other than mother and offspring. Unable to use the models in standard parentage software packages to assign probabilities to given relationship hypotheses, we sought direct, empirical evidence of exclusion power. Specifically, we searched for potential parents in a published dataset of 473 polar bear genotypes (Paetkau et al., 1999) 


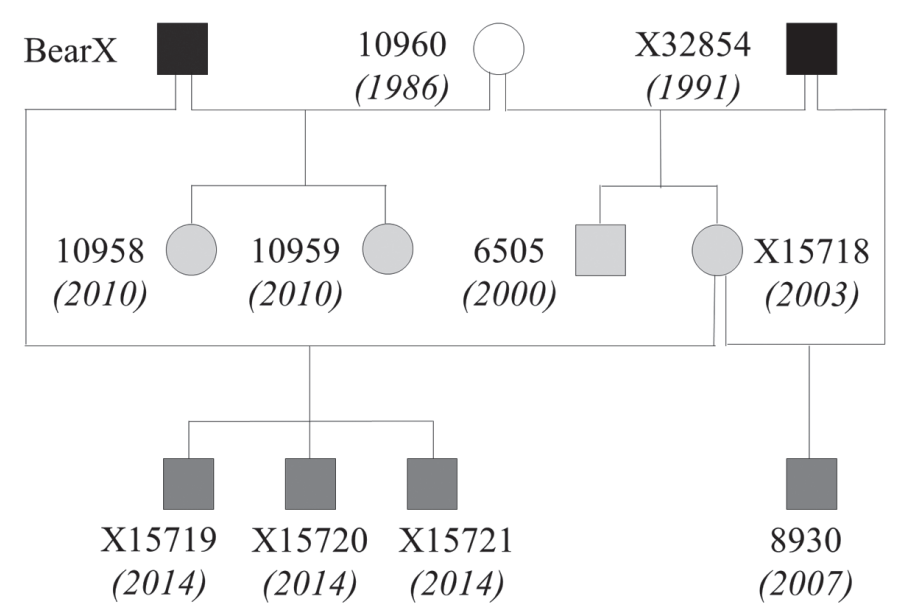

FIG. 4. Pedigree of hybrid bears (and associated polar and grizzly bears) identified through DNA analysis. Symbols represent males (squares) and females (circles) of polar bears (white), F1 hybrids (light grey), GBC1 hybrids (dark grey), and grizzly bears (black). Birth years are noted in parentheses. For identification of bears, see Table 2.

that included data for 16 of the 21 microsatellite markers in our dataset. None of these 473 individuals shared alleles at every marker with any of the three individuals of interest (X15718, 6505, 8930). This demonstrates that allele sharing at 16 markers, much less 21 markers, is unlikely to occur by chance, and thus supports the eight mother-offspring relationships that we identified.

The mitochondrial analysis identified the same polar bear haplotype (Clade I of Waits et al., 1998) in female 10960 and in all eight hybrids, as would be expected if they all trace their maternal ancestry to that female, as we propose. The male grizzly X32854 had the Clade III haplotype characteristic of northern grizzlies.

Considering fathers, we searched the genotypes of 1250 grizzly bears that had data for at least eight of the markers in our dataset. These bears were from the barren grounds of Nunavut (M. Awan, Government of Nunavut, Department of Environment, pers. comm. 2016), the northern Northwest Territories (Government of Northwest Territories, Environment and Natural Resources, unpubl. data), and northern Yukon (R. Maraj, Government of Yukon, Environment Yukon, pers. comm. 2016). We identified three cases in which the genotype of a male grizzly bear exactly complemented the contribution of the mother to explain the heredity of each allele observed in the genotype of a hybrid bear. In all three cases, the suggested father was X32854, a bear that had one of the most northerly sampling locations of any grizzly bear to date (Fig. 2). The fact that all 1250 individuals were excluded as the grizzly bear parent of five hybrid offspring, and that 1249 individuals of the same set were excluded as the grizzly bear parent of the other three hybrids, despite using data for as few as eight markers, demonstrates the remarkable power of these markers to exclude non-parents of hybrid offspring. Given this demonstrated exclusion power, the improbability that X32854 alone would be placed as the father of multiple hybrid offspring by chance, and the fact that subsequent analysis of six extra markers for this family group failed to identify any mismatches between putative parent and offspring, we conclude that X32854 is indeed the father of two F1 bears $(6505, \mathrm{X} 15718)$ and a single GBC1 bear (8930). The identification of X32854 as the father of three hybrid individuals revealed a father-daughter mating, in which X32854 mated with his F1 daughter X15718 to produce the GBC1 individual 8930 (Fig. 4).

No genotype that we could find explained the paternal contributions to the three offspring captured with X15718 (X15719, X15720, X15721). Starting with the assumption that all three offspring shared the same father, we deduced the paternal genotype by compiling the alleles in the genotypes of the three offspring that could not have come from the mother, X15718. Remarkably, this deduced genotype, which we identify as BearX, also explained every paternal allele in the genotypes of the two cubs identified with the female polar bear $10960(10958,10959)$. Given the low probability of chance matches that we demonstrated by excluding 1250 previously genotyped grizzly bears, this effectively confirms BearX as the father of five hybrid offspring (10958, 10959, X15719, X15720, X15721). BearX's deduced genotype was heterozygous at 14 of 21 markers, which is consistent with the variability observed in northern grizzly bear populations (Paetkau et al., 1998b). BearX's genotype is likely to be complete, or nearly so, since the probability of a father passing the same allele at a heterozygous locus to all five offspring is only $1 / 16$, meaning that at 15 of 16 heterozygous loci, on average, both alleles in a parent's genotype would be seen in the genotype of at least one of five offspring.

The combination of field observations and pedigree suggests that our sample set included four F1 hybrids (10958, 10959, 6505, X15718) and four GBC1 individuals (X15719, X15720, X15721, 8930) (Fig. 4, Table 2). We tested these implied ancestry states using genotype-based principal component analysis (PCA) and data from 4000 genotypes that we generated by random sampling to represent the four ancestries of interest. In the first dimension of the PCA, there was no overlap in the distributions of values for polar bears, F1s, and grizzly bears, indicating near perfect power to resolve these three ancestry states (Fig. 5). In contrast, the distribution of GBC1 genotypes overlapped with those of F1s and grizzly bears, with only $86 \%$ of GBC1 genotypes having values that were both above $95 \%$ of $\mathrm{F} 1$ values and below $95 \%$ of grizzly bear values. Only $68 \%$ of GBC1 genotypes sat between $99 \%$ of F1 and grizzly bear genotypes. Furthermore, our random sampling procedure was simplistic and relied on just 30 individuals per species to establish allele frequencies, so it is possible that we underestimated the degree of overlap between GBC1 genotypes and the others. Our intention here was to achieve a qualitative confirmation of the ancestries established by pedigrees, not to assign probabilities to particular ancestry hypotheses. 
TABLE 2. List of bears identified in the hybrid pedigree (Fig. 4), with bear ID, species, sex, year of identification, and associated information. Species are grizzly bear (GB), polar bear (PB), first-generation hybrid (F1), and backcross-to-grizzly-bear (GBC1).

\begin{tabular}{|c|c|c|c|c|}
\hline Bear ID & Species & Sex & Year & Associated information \\
\hline BearX & GB & M & unknown & Hypothesized grizzly bear based on DNA profile deduced from offspring \\
\hline 10960 & $\mathrm{~PB}$ & $\mathrm{~F}$ & 2012 & Harvested along with two two-year-old offspring \\
\hline X32854 & GB & M & 2012 & Captured north of Victoria Island \\
\hline 10959 & $\mathrm{~F} 1$ & $\mathrm{~F}$ & 2012 & Two-year-old harvested with mother (10960) \\
\hline 10958 & $\mathrm{~F} 1$ & $\mathrm{~F}$ & 2012 & Two-year-old harvested with mother (10960) \\
\hline 6505 & F1 & M & 2006 & Harvested south of Banks Island \\
\hline $\mathrm{X} 15718$ & $\mathrm{~F} 1$ & $\mathrm{~F}$ & 2014 & Captured with three cubs-of-the-year \\
\hline $\mathrm{X} 15719$ & $\mathrm{GBC} 1$ & $\mathrm{M}$ & 2014 & Cub-of-the-year captured with mother (X15718) \\
\hline $\mathrm{X} 15720$ & GBC1 & M & 2014 & Cub-of-the-year captured with mother (X15718) \\
\hline X15721 & GBC1 & M & 2014 & Cub-of-the-year captured with mother (X15718) \\
\hline 8930 & GBC1 & $\mathrm{M}$ & 2010 & Harvested in west Victoria Island \\
\hline
\end{tabular}

Comparing the 10 genotyped bears in the pedigree (Fig. 4) and the deduced genotype of BearX to the distributions produced by random sampling, we found that the presumed F1s and GBC1s all sat comfortably within the ranges expected for those ancestry states, while 10960 and $\mathrm{X} 32854$, the mating pair that gave rise to the original Sachs F1 (6505), were grouped with their parental species (one polar bear and one grizzly), outside the ranges of values observed for F1 and $\mathrm{GBCl}$ genotypes (Fig. 5). As expected from the physical appearance of his offspring, Bear X's genotype clustered with that of northern grizzly bears (Fig. 5).

\section{DISCUSSION}

Our genetic analysis confirmed expectations from field observations, identifying four F1 hybrids and four GBC1 individuals. The polar bear ancestry of these eight individuals traced to a single female polar bear (10960) who mated with two grizzly bears, one of which was sampled in the High Arctic (X32854) and the other (BearX) whose genotype we deduced from his five offspring. These two grizzly bears were also the sires of the GBC1 generation, so what appeared at first to be a sudden spate of hybridization is reduced to the unusual mating activities of three nonhybrid parents (Fig. 3).

While we cannot predict the relevance of these events to the future, existing data from polar bears and grizzly bears indicate that introgression has not been a meaningful feature of the recent history of northern Canadian grizzly bears and polar bears. For example, the allele size ranges at marker G10L are non-overlapping between barren ground grizzlies and polar bears (Paetkau et al., 1997: Appendix A), a pattern that was confirmed in a sample of 473 polar bears spanning the species range (Paetkau et al., 1999). By contrast, the shorter alleles characteristic of polar bears are observed at low frequency in the brown bears of southeastern Alaska (D. Paetkau, unpubl. data), where an ancient introgression event saw polar bears contribute to the ancestry of the regional population (Cahill et al., 2013, 2015). With microsatellite mutation rates on the order of one per several hundred generations (Weber and Wong,
1993), it would take hundreds or thousands of generations to establish non-overlapping allele size ranges, and even small rates of gene flow many generations in the past would introduce grizzly bear alleles that would remain detectable today. Clustering analysis (program Genetix) and assignments of individual ancestry (program Structure) based on the 15 core markers in our dataset also failed to find any evidence of mixed species ancestry in a sample of published and unpublished genotypes from 4650 polar bears (data from Peacock et al., 2015; Paetkau et al., 1999; unpubl. genotypes from Alaska, T. Atwood, U.S. Geological Survey, pers. comm. 2016; from Nunavut, M. Dyck, Government of Nunavut, Department of Environment, pers. comm. 2016; from the Northwest Territories, Government of Northwest Territories, Environment and Natural Resources, unpubl. data). Thus, despite powerful short-term and long-term detection systems, the only evidence we find of hybridization is the extended family that we describe here. This result is consistent with other recent research that found no evidence for grizzly bear introgression into modern polar bear populations (Cahill et al., 2013, 2015; Liu et al., 2014; Peacock et al., 2015).

The primary conservation concern raised by these observations is that the polar bear population as a whole would be subsumed by male-mediated gene flow from grizzly bears, as has been posited to have happened to a relictual polar bear population in the islands of southeastern Alaska at the end of the Pleistocene (Cahill et al., 2013). Until we see evidence of successful matings between hybrids and polar bears, this threat is not substantiated. The fact that the hybrid F1 mated with two different grizzly bears rather than polar bears, despite the latter being far more abundant in the region, is consistent with a behavioural barrier that prevents polar bears from being genetically swamped by grizzly bears, in whose presence polar bears have long maintained an independent evolutionary course.

In the last decade, grizzly bears have become more common on the Arctic Islands, concurrent with environmental change. Our observation that grizzly bear range expansion is driven by males is consistent with the concept of sex-biased dispersal: namely, that males disperse farther distances from natal home ranges than females 


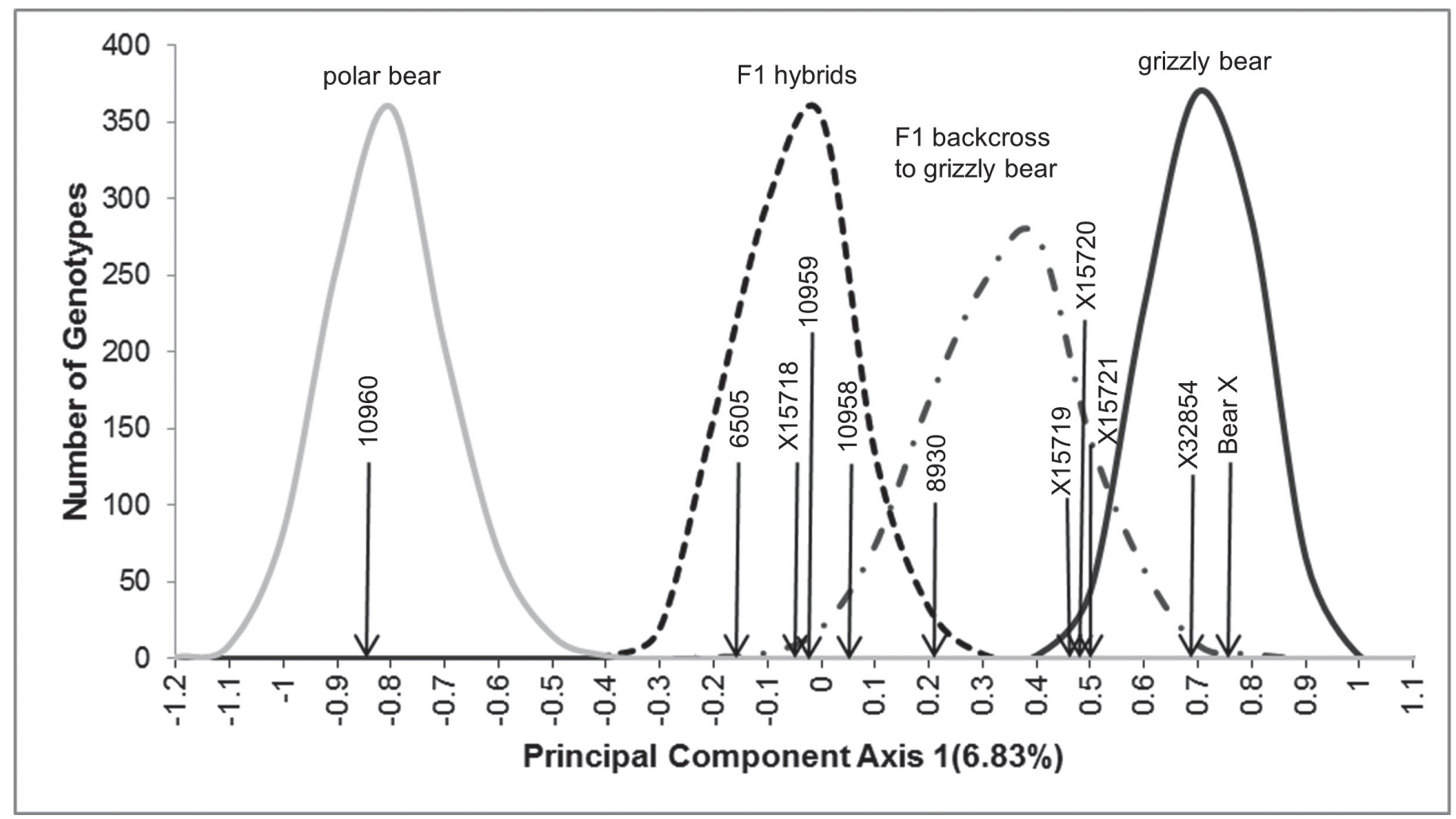

FIG. 5. The distribution of Axis 1 values from the principal component analysis, highlighting where individuals from the pedigree appear in relation to simulated genotypes of polar bears (light grey), F1 hybrids (dashed), GBC1 hybrids (dash-dot), and grizzly bears (black).

do (Glenn and Miller, 1980; Blanchard and Knight, 1991; McLellan and Hovey, 2001; Kojola et al., 2003; Støen et al., 2006). Theory suggests that hybridization is more frequent at the expanding edge of a species' range, where that species exists at low densities (Arnold, 1997) and thus may face reduced options with respect to mating (in this situation, reduced or absent female grizzly bears). To the extent that range expansion is likely to be linked to climate change, this theory creates a plausible link between this breakdown of assortative mating and larger climatic patterns.

The story becomes less clear when we consider that both documented grizzly bear sires of hybrid offspring (X32854 and BearX) mated with the same female polar bear (10960). Given that many female polar bears are potentially available for breeding in the region, this remarkable coincidence suggests an element of individual mate choice. Whether or not these events have a lasting impact, there is value in considering the ecological factors that may have contributed to them. For many mammalian species, sexual selection is driven by mate choice by females and malemale mate competition (Shuster, 2009). In theory, females of many species have a stronger mate selection than males because they have greater parental investment (Orians, 1969; Trivers, 1972) and select males for their genetic quality on the basis of behavioural and morphological characteristics that reflect fitness (Orians, 1969), such as aggression (and signs thereof), body size, and weaponry, e.g., claws (Andersson, 1994). The high degree of sexual dimorphism apparent in both bear species is understood to be a result of this selection (Andersson, 1994; Zedrosser et al., 2007). Anecdotal information describes grizzly bears as more agile and aggressive when fighting polar bears and suggests that they dominate in confrontations and can fatally injure polar bears (Joint Secretariat, 2015). Grizzly bears have also demonstrated social dominance when interacting with polar bears at feeding areas during autumn (Miller et al., 2015). Furthermore, although polar bears are the more common species in the greater western Arctic Islands, more grizzly and hybrid bears than polar bears were sighted within the Wynniatt Bay region during recent polar bear work in $2012-14$. It is conceivable that an increase in hybrid and grizzly bear activity within the region may have deterred the presence of polar bears. Thus it is plausible that aggressiveness may have played a direct or indirect role in the hybridization events we documented.

Independent of mate choice, other commonalities of the mating systems between these species must be satisfied for successful mating to occur. Behavioural elements of grizzly bear and polar bear mating systems are similar in that they involve the sequestering of females by males into confined areas (Herrero and Hamer, 1977; Ramsay and Stirling, 1986; Hamer and Herrero, 1990; Stirling et al., 2016), presumably for the duration of her oestrus, to ensure successful fertilization (Herrero and Hamer, 1977). Temporal and spatial overlaps are also necessary. Polar bears mate from March through June (Ramsay and Stirling, 1986; Stirling et al., 2016), and grizzly bears, from April through July (Herrero and Hamer, 1977; Hamer 
and Herrero, 1990; White et al., 1998; Stenhouse et al., 2005; Fernández-Gil et al., 2006; Spady et al., 2007). It is understood that polar bears seek mates in optimal habitat; females distribute themselves in areas with optimal hunting potential, and males use these habitats in search of females (Ramsay and Stirling, 1986). Grizzly bears have also been observed to aggregate in areas where abundant and predictable food sources exist (i.e., Peirce et al., 2013); however, spatial segregation data suggest that adult females with cubs avoid these areas to avoid risk of infanticide (Ben-David et al., 2004) rather than choosing them as a place to encounter mates. This contrast may have to do with timing, as aggregations are associated with salmon spawning, which typically occurs after mating. It has also been suggested that discrete mating areas (not related to abundant food sources) may be used by small and fragmented grizzly bear populations to facilitate encountering a mate (Fernández-Gil et al., 2006). Barren ground grizzly bears do not have sites where abundant and predictable food sources exist, nor do they encounter sea ice across much of their range, although hunters from coastal communities along the mainland Northwest Territories (Tuktoyaktuk and Paulatuk) have observed signs of grizzly bears hunting on the sea ice and feeding on seals, and some suggest that they are seeing this activity more frequently than they used to (Joint Secretariat, 2015).

Previous descriptions of polar bear mating systems have found that mating among first-degree relatives is rare (Zeyl et al., 2009; Malenfant et al., 2016). Yet this behaviour, however uncommon, has been documented in grizzly bears, resulting in offspring from a male grizzly bear and two of his female offspring (Cronin et al., 2005). Perhaps any breakdown of species barriers starts with a single individual with atypical mating preferences, and the evolutionary importance of this story is not undermined by the fact that it was traced to a single polar bear. Alternatively, these events could be nothing more than a single polar bear with unusual mating preferences, who, along with three of her four documented F1 offspring, has now been harvested, and whose descendants have not yet been documented to have mated successfully with polar bears, potentially rendering them irrelevant to the species' future. Only time and observation can establish which of these interpretations is correct.

\section{ACKNOWLEDGEMENTS}

We thank the Inuvialuit hunters and Environment and Natural Resources patrolmen for providing samples and information that made much of this work possible, as well as Christine Menno, lab technician for Environment and Natural Resources, Inuvik Region. We thank Peter Ross Klengenberg, Andrew Derocher, Thea Bechshoft, Nick Pilfold, Mike Woodcock, Patrick Fonseca, and Benedikt Segura for their invaluable assistance in the field. We gratefully acknowledge support from Environment and Climate Change Canada, the Government of the Northwest Territories, the Government of Nunavut, Inuvialuit Implementation funds, the Nunavut Wildlife Management Board, the Polar Continental Shelf Program, and the World Wildlife Fund.

\section{REFERENCES}

Andersson, M. 1994. Sexual selection. Princeton: Princeton University Press.

Arnold, M.L. 1997. Natural hybridization and evolution. Oxford: Oxford University Press.

Ben-David, M., Titus, K., and Beier, L.R. 2004. Consumption of salmon by Alaskan brown bears: A trade-off between nutritional requirements and the risk of infanticide? Oecologia 138(3):465-474.

https://doi.org/10.1007/s00442-003-1442-x

Blanchard, B.M., and Knight, R.R. 1991. Movements of Yellowstone grizzly bears. Biological Conservation 58(1):41-67.

https://doi.org/10.1016/0006-3207(91)90044-A

Breen, M., Jouquand, S., Renier, C., Mellersh, C.S., Hitte, C., Holmes, N.G., Chéron, A., et al. 2001. Chromosomespecific single-locus FISH probes allow anchorage of an 1800-marker integrated radiation-hybrid/linkage map of the domestic dog genome to all chromosomes. Genome Research 11(10):1784-1795. https://doi.org/10.1101/gr.189401

Cahill, J.A., Green, R.E., Fulton, T.L., Stiller, M., Jay, F., Ovsyanikov, N., Salamzade, R., et al. 2013. Genomic evidence for island population conversion resolves conflicting theories of polar bear evolution. Genetics 9(3): e1003345. https://doi.org/10.1371/journal.pgen.1003345

Cahill, J.A., Stirling, I., Kistler, L., Salamzade, R., Ersmark, E., Fulton, T.L., Stiller, M., Green, R.E., and Shapiro, B. 2015. Genomic evidence of geographically widespread effect of gene flow from polar bears into brown bears. Molecular Ecology 24(6):1205-1217.

https://doi.org/10.1111/mec.13038

Canadian Ice Service. 2013. Sea ice climatic atlas for the northern Canadian waters 1981-2010. Ottawa: Environment and Climate Change Canada.

https://www.ec.gc.ca/glaces-ice/default.asp?lang=En\&n= 4B35305B-1

Cronin, M.A., and MacNeil, M.D. 2012. Genetic relationships of extant North American brown bears (Ursus arctos) and polar bears (U. maritimus). Journal of Heredity 103(6):873-881. https://doi.org/10.1093/jhered/ess090

Cronin, M.A., Shideler, R., Waits, L., and Nelson, R.J. 2005. Genetic variation and relatedness in grizzly bears in the Prudhoe Bay region and adjacent areas in northern Alaska. Ursus 16(1):70-84.

https://doi.org/10.2192/1537-6176(2005)016[0070:GVARIG]2. $0 . \mathrm{CO} ; 2$ 
Cronin, M.A., McDonough, M.M., Huynh, H.M., and Baker, R.J. 2013. Genetic relationships of North American bears (Ursus) inferred from amplified fragment length polymorphisms and mitochondrial DNA sequences. Canadian Journal of Zoology 91(9):626-634.

https://doi.org/10.1139/cjz-2013-0078

Cronin, M.A., Rincon, G., Meredith, R.W., MacNeil, M.D., IslasTrejo, A., Cánovas, A., and Medrano, J.F. 2014. Molecular phylogeny and SNP variation of polar bears (Ursus maritimus), brown bears (U. arctos) and black bears (U. americanus) derived from genome sequences. Journal of Heredity 105(3):312-323. https://doi.org/10.1093/jhered/est133

Doupé, J.P., England, J.H., Furze, M., and Paetkau, D. 2007. Most northerly observation of a grizzly bear (Ursus arctos) in Canada: Photographic and DNA evidence from Melville Island, Northwest Territories. Arctic 60(3):271-276. https://doi.org/10.14430/arctic219

Ennis, S., and Gallagher, T.F. 1994. A PCR-based sexdetermination assay in cattle based on the bovine amelogenin locus. Animal Genetics 25(6):425-427. https://doi.org/10.1111/j.1365-2052.1994.tb00533.x

Fernández-Gil, A., Naves, J., and Delibes, M. 2006. Courtship of brown bears Ursus arctos in northern Spain: Phenology, weather, habitat and durable mating areas. Wildlife Biology 12(4):367-373.

https://doi.org/10.2981/0909-6396(2006)12[367:COBBUA]2.0. $\mathrm{CO} ; 2$

Glenn, L.P., and Miller, L.H. 1980. Seasonal movements of an Alaska Peninsula brown bear population. Bears: Their Biology and Management 4:307-312. https://doi.org/10.2307/3872885

Hailer, F., Kutschera, V.E., Hallström, B.M., Klassert, D., Fain, S.R., Leonard, J.A., Arnason, U., and Janke, A. 2012. Nuclear genomic sequences reveal that polar bears are an old and distinct bear lineage. Science 336(6079):344-347. https://doi.org/10.1126/science.1216424

Hamer, D., and Herrero, S. 1990. Courtship and use of mating areas by grizzly bears in the front ranges of Banff National Park, Alberta. Canadian Journal of Zoology 68(12):2695-2697. https://doi.org/10.1139/z90-373

Herrero, S., and Hamer, D. 1977. Courtship and copulation of a pair of grizzly bears, with comments on reproductive plasticity and strategy. Journal of Mammalogy 58(3):441 - 444. https://doi.org/10.2307/1379352

Hudson, E., Aihoshi, D., Gaines, T., Simard, G., and Mullock, J. 2001. The weather of Nunavut and the Arctic: Graphic area forecast 36 and 37. Ottawa: NAV CANADA.

http://www.navcanada.ca/EN/media/Publications/Local\%20 Area\%20Weather\%20Manuals/LAWM-Arctic-1-EN.pdf

Joint Secretariat. 2015. Inuvialuit and Nanuq: A polar bear traditional knowledge study. Inuvik: Joint Secretariat. http://www.wmacns.ca/current/projects/37/

Kitahara, E., Isagi, Y., Ishibashi, Y., and Saitoh, T. 2000. Polymorphic microsatellite DNA markers in the Asiatic black bear Ursus thibetanus. Molecular Ecology 9(10):1661 - 1662. https://doi.org/10.1046/j.1365-294x.2000.01030.x
Kojola, I., Danilov, P.I., Laitala, H.-M., Belkin, V., and Yakimov, A. 2003. Brown bear population structure in core and periphery: Analysis of hunting statistics from Russian Karelia and Finland. Ursus 14(1):17-20.

Liu, S., Lorenzen, E.D., Fumagalli, M., Li, B., Harris, K., Xiong, Z., Zhou, L., et al. 2014. Population genomics reveal recent speciation and rapid evolutionary adaptation in polar bears. Cell 157(4):785-794.

https://doi.org/10.1016/j.cell.2014.03.054

Malenfant, R.M., Coltman, D.W., Richardson, E.S., Lunn, N.J., Stirling, I., Adamowicz, E., and Davis, C.S. 2016. Evidence of adoption, monozygotic twinning, and low inbreeding rates in a large genetic pedigree of polar bears. Polar Biology 39(8):1455- 1465.

https://doi.org/10.1007/s00300-015-1871-0

McLellan, B.N., and Hovey, F.W. 2001. Natal dispersal of grizzly bears. Canadian Journal of Zoology 79(5):838-844.

https://doi.org/10.1139/z01-051

Miller, W., Schuster, S.C., Welch, A.J., Ratan, A., BedoyaReina, O.C., Zhao, F., Kim, H.L., et al. 2012. Polar and brown bear genomes reveal ancient admixture and demographic footprints of past climate change. Proceedings of the National Academy of Sciences of the United States of America 109(36): E2382-E2390.

https://doi.org/10.1073/pnas.1210506109

Miller, S., Wilder, J., and Wilson, R.R. 2015. Polar bear-grizzly bear interactions during the autumn open-water period in Alaska. Journal of Mammalogy 96(6):1317-1325.

https://doi.org/10.1093/jmammal/gyv140

Orians, G.H. 1969. On the evolution of mating systems in birds and mammals. The American Naturalist 103(934):589-603. https://doi.org/10.1086/282628

Paetkau, D., Waits, L.P., Clarkson, P.L., Craighead, L., and Strobeck, C. 1997. An empirical evaluation of genetic distance statistics using microsatellite data from bear (Ursidae) populations. Genetics 147(4):1943-1957.

Paetkau, D., Shields, G.F., and Strobeck, C. 1998a. Gene flow between insular, coastal and interior populations of brown bears in Alaska. Molecular Ecology 7(10):1283-1292. https://doi.org/10.1046/j.1365-294x.1998.00440.x

Paetkau, D., Waits, L.P., Clarkson, P.L., Craighead, L., Vyse, E., Ward, R., and Strobeck, C. 1998b. Variation in genetic diversity across the range of North American brown bears. Conservation Biology 12(2):418-429. https://doi.org/10.1111/j.1523-1739.1998.96457.x

Paetkau, D., Amstrup, S.C., Born, E.W., Calvert, W., Derocher, A.E., Garner, G.W., Messier, F., et al. 1999. Genetic structure of the world's polar bear populations. Molecular Ecology 8(10): $1571-1584$. https://doi.org/10.1046/j.1365-294x.1999.00733.x

Peacock, E., Sonsthagen, S.A., Obbard, M.E., Boltunov, A., Regehr, E.V., Ovsyanikov, N., Aars, J., et al. 2015. Implications of the circumpolar genetic structure of polar bears for their conservation in a rapidly warming Arctic. PLOS ONE 10(8): e112021.

https://doi.org/10.1371/journal.pone.0112021 
Peirce, J.M., Otis, E.O., Wipfli, M.S., and Follmann, E.H. 2013. Interactions between brown bears and chum salmon at McNeil River, Alaska. Ursus 24(1):42-53. https://doi.org/10.2192/URSUS-D-12-00006.1

Ramsay, M.A., and Stirling, I. 1986. On the mating system of polar bears. Canadian Journal of Zoology 64(10):2142-2151. https://doi.org/10.1139/z86-329

Shuster, S.M. 2009. Sexual selection and mating systems. Proceedings of the National Academy of Sciences of the United States of America 106(Suppl. 1):10009-10016. https://doi.org/10.1073/pnas.0901132106

Spady, T.J., Lindburg, D.G., and Durrant, B.S. 2007. Evolution of reproductive seasonality in bears. Mammal Review 37(1):21-53. https://doi.org/10.1111/j.1365-2907.2007.00096.x

Stenhouse, G., Boulanger, J., Lee, J., Graham, K., Duval, J., and Cranston, J. 2005. Grizzly bear associations along the eastern slopes of Alberta. Ursus 16(1):31 - 40. https://doi.org/10.2192/1537-6176(2005)016[0031:GBAATE]2. $0 . \mathrm{CO} ; 2$

Stirling, I., Spencer, C., and Andriashek, D. 2016. Behavior and activity budgets of wild breeding polar bears (Ursus maritimus). Marine Mammal Science 32(1):13-37. https://doi.org/10.1111/mms.12291

Støen, O.-G., Zedrosser, A., Sæbø, S., and Swenson, J.E. 2006. Inversely density-dependent natal dispersal in brown bears Ursus arctos. Oecologia 148(2):356-364.

https://doi.org/10.1007/s00442-006-0384-5
Taberlet, P., Camarra, J.-J., Griffin, S., Uhrès, E., Hanotte, O., Waits, L.P., Dubois-Paganon, C., Burke, T., and Bouvet, J. 1997. Noninvasive genetic tracking of the endangered Pyrenean brown bear population. Molecular Ecology 6(9):869-876. https://doi.org/10.1111/j.1365-294X.1997.tb00141.x

Trivers, R.L. 1972. Parental investment and sexual selection. Cambridge, Massachusetts: Biological Laboratories, Harvard University.

Waits, L.P., Talbot, S.L., Ward, R.H., and Shields, G.F. 1998. Mitochondrial DNA phylogeography of the North American brown bear and implications for conservation. Conservation Biology 12(2):408-417. https://doi.org/10.1111/j.1523-1739.1998.96351.x

Weber, J.L., and Wong, C. 1993. Mutation of human short tandem repeats. Human Molecular Genetics 2(8):1123-1128. https://doi.org/10.1093/hmg/2.8.1123

White, D., Jr., Berardinelli, J.G., and Aune, K.E. 1998. Reproductive characteristics of the male grizzly bear in the continental United States. Ursus 10:497-501.

Zedrosser, A., Bellemain, E., Taberlet, P., and Swenson, J.E. 2007. Genetic estimates of annual reproductive success in male brown bears: The effects of body size, age, internal relatedness and population density. Journal of Animal Ecology 76(2):368-375.

https://doi.org/10.1111/j.1365-2656.2006.01203.x

Zeyl, E., Aars, J., Ehrich, D., and Wiig, Ø. 2009. Families in space: Relatedness in the Barents Sea population of polar bears (Ursus maritimus). Molecular Ecology 18(4):735-749. https://doi.org/10.1111/j.1365-294X.2008.04049.x 